Pamiętnik Literacki 2018, 4, s. 165-184

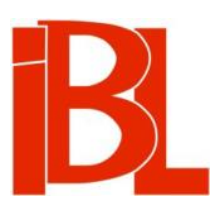

\title{
Dzieła upowszechnione pod nazwiskiem Duretiusa w krakowskiej edycji
}

\author{
Jarosław Nowaszczuk
}


Pamiętnik Literacki CIX, 2018, z. 4, PL ISSN 0031-0514

DOI: $10.18318 / \mathrm{pl} .2018 .4 .10$

JAROSŁAW NOWASZCZUK Uniwersytet Szczeciński

\section{DZIEŁA UPOWSZECHNIONE POD NAZWISKIEM DURETIUSA W KRAKOWSKIEJ EDYCJI}

W bibliografii Karola Estreichera pojawia się krótka wzmianka, która dotyczy Quintinusa Duretiusa, benedyktyna pochodzącego z terenów dzisiejszej Belgii ${ }^{1}$. Zakonnik ten najprawdopodobniej nigdy nie był w Polsce, ale w Rzeczypospolitej Obojga Narodów czytano utwór rozpowszechniony pod jego nazwiskiem. Krakowski uczony odnotowuje tytuł tego dzieła: "Litaniae lavretanae” anagrammaticè contextae. Corona quoquè V. Beatissimae, ex S. Scripturae elogijs versu composita ${ }^{2}$. Strona tytułowa zbioru poetyckiego dostarcza kilku informacji o niewielkim wydaniu, pozwala też uświadomić sobie istniejące niejasności. Wątpliwości nie budzi miejsce druku. U dołu karty zostało bowiem podane wprost, że całość ukazała się w Krakowie w oficynie wdowy i spadkobierców Franciszka Cezarego („Officina Viduae et Haeredum Francisci Cesarii S. R. M. typog."). Zamieszczono tam również dopisek, iż jest to wznowienie (secundis curis), gdyż kolekcje po raz pierwszy wydrukowano w Antwerpii („Antverpiae primum impressa”). W tym samym miejscu pojawia się też wzmianka o autorze: Quintinus Duretius to wielebny i nadzwyczaj uczony mnich ze zgromadzenia św. Benedykta, profesor sztuki wymowy w zakonnej uczelni w miejscowości o łacińskiej nazwie Gerardimontium („Ab adm. rndo et doctissimo patre, Quintino Duretio Ord. S. Benedicti, in Gerardimontensi universitate Benedictina, eloquentiae publico professore"). Przekazane w skondensowanej postaci dane

K. Estreich er, Bibliografia polska. T. 15. Kraków 1897, s. 416.

Forma tytułu w przytoczonej postaci różni się od tej, jaka widnieje na stronie tytułowej oryginału dzieła Q. D u r e ti u s a, czyli: "Litaniae Lauretanae” anagrammatice contextae. Corona quoque V. Beatissimae, ex S. Scripturae elogiis versu composita (Cracoviae, b. r.). Dalej do pozycji tej odsyłam skrótem L. Ponadto wprowadzam skrót Rh na oznaczenie edycji flandryjskiej benedyktyna: Rhetorum Collegii S. Adriani oppidi Gerardimontani in Flandria „Poesis anagrammatica”. Antverpiae 1651. Dzieło to jest zamieszczone na stronie: https://books.google.de/books?id=Pl3UFyqUFaEC\&print $\mathrm{sec}=$ frontcover\&hl=pl\&source=gbs_ge_summary_r\&cad=0\#v=onepage $\& q \& \mathrm{f}=$ false $($ data dostępu: 4 VIII 2018). Liczby lub oznaczenia po skrótach wskazują stronice bądź karty. Zdarza się, że księgi te nie posiadają paginacji. Wówczas podaję tylko skrót. We wszystkich cytatach łacińskich dostosowano zapis do norm łaciny klasycznej, rezygnując $z$ form zawartych w przywoływanych dziełach. Oryginalne wersje zachowano jedynie w tabeli prezentującej różnorodne rozwiązania anagramatyczne utworzone na podstawie wezwań Litanii loretańskiej.

Dwa egzemplarze wydania $z$ Krakowa znajduja się w zbiorach Bibl. Jagiellońskiej (opatrzone sygnaturami BJ St. Dr. 588524 I oraz BJ St. Dr. 805 I). Książka oznaczona drugą z wymienionych sygnatur jest dostępna w wersji elektronicznej na stronie: http://jbc.bj.uj.edu.pl/publication/290447/content (data dostępu: 4 VIII 2018). 
nie wyjaśniają w pełni pytań dotyczących twórcy i jego dorobku oraz motywów, jakie skłoniły polskiego edytora do reedycji książki. Ona sama może również intrygować. Brak bowiem, jak dotąd, omówień precyzujących, czy „Litaniae Lauretanae” anagrammatice contextae to bliźniacze wznowienie, czy raczej dzieło poddane nowej redakcji. Do wyjaśnienia pozostaje także, w którym roku ukazało się w Polsce i jaka jest jego zawartość treściowa.

\section{Rektor benedyktyńskiego kolegium}

Nieliczne wiadomości dotyczące odnotowanego przez Estreichera autora - potwierdzające te wcześniej tu przekazane - zawiera Bibliotheca Belgica [...] Johannesa Franciscusa Foppensa. Badacz rodem $z$ Brukseli zamieszcza w drugim tomie swego opracowania wydanego w 1739 roku następujący biogram:

Quintinus Duretius, Insulensis, Monasterii S. Adriani Ordinis S. Benedicti oppidi Gerardimontensis in Flandria Religiosus, Rectorque Gymnasii ad erudiendam juventutem a S. P. Q. Gerardimontibus erecti, edidit Rhetorum Collegii S. Adriani Gerardim. „Poesin anagrammaticam” 8. Antv[erpiae]: apud Petr[um] Bellerum 1651. [Quintinus Duretius z Lille, zakonnik benedyktyńskiego klasztoru pod wezwaniem świętego Adriana w miejscowości Gerardimontium we Flandrii oraz przełożony tamtejszego gimnazjum ufundowanego przez lokalne władze i mieszkańców, by kształcić młodzież. Wydał w formacie in octavo u Petrusa Bellera w Antwerpii książkę Poezja anagramatyczna retorów Kolegium Świętego Adriana $w$ Gerardimontium. $]^{3}$

Jeszcze bardziej zwięzłą charakterystykę postaci zawiera pochodzące - podobnie zresztą jak traktat Foppensa - z XVIII wieku dzieło poświęcone historii piśmiennictwa benedyktyńskiego. Jego redaktorzy określają autora „Litaniae Lauretanae” zaledwie jednym zdaniem: „Quintinus Duretius, Gerardimontensis Collegii Rector cl. c. a. 1651 [Quintinus Duretius, przełożony kolegium w Gerardimontium, stał się znany około roku 1651]"4.

Przywołane dotąd źródła wskazują, że zakonnik spędził życie na terenach dawnej Flandrii. Tam leżało bowiem miasto Lille, miejsce jego urodzenia, znajdujące się współcześnie po francuskiej stronie granicy. Tam poszukiwać należy również miejscowości Gerardimontium, która dziś należy do Belgii. Źródła z epoki pozwalają łatwo ustalić, że było to miasto określane dawniej: Gheertsberghe, a obecnie znane pod endemiczną nazwą Geraardsbergen albo francuską Grammont. Mapa opracowana przez Joana Blaeu nie pozostawia wątpliwości, iż chodzi właśnie o to miejsce. Rycina znalazła się w latach czterdziestych XVII stulecia w dziele Antoniusa Sanderusa Flandria illustrata. Towarzyszy jej obszerny wywód o historii osady, jej obywatelach i najważniejszych budowlach ${ }^{5}$. Widok na miasto wznowiono następnie w Novum ac magnum theatrum urbium Belgicae Liberae ac Foederatae ${ }^{6}$.

J. F. F o p p en s, Bibliotheca Belgica, sive virorum in Belgio vita, scriptisque illustrium catalogus, librorumque nomenclatura [...]. T. 2. Bruxellis 1739, s. 1050.

$4 \quad$ M. Zi egelbau er, O. Legi ontius, Historia rei litterariae Ordinis S. Benedicti [...]. Cz. 3: Biographica. Herbipoli 1754, s. 619.

5 W obecnym opracowaniu posłużono się późniejszą edycją: A. S a n d e r u s, Flandria illustrata sive Provinciae ac Comitatus huius descriptio. T. 3. Bruxellis 1735, s. 168-169 (rycina), s. 166-179 (opis miasta).

$6 \quad$ J. Bla e u, Toonneel der steden van de Vereenighde Nederlanden. T. 1. Amstelodami 1649, k. iijLv. 
Na środku grafiki znajduje się napis: „Gerardimontium vulgo Gheertsberghe [Gerardimontium potocznie Gheertsberghe]”.

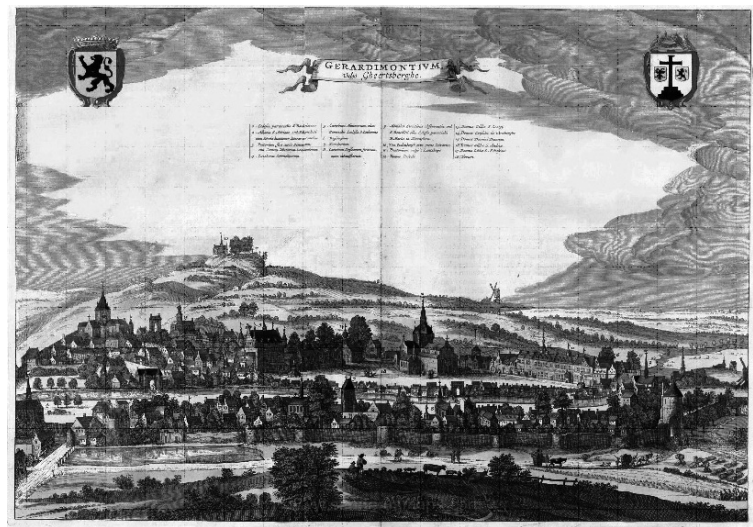

Widok na Gheertsberghe w opracowaniu J. Blaeu

Gród - w postaci, jaką uchwycił w swym dziele artysta - był środowiskiem życia Quintinusa Duretiusa. Chalkograf jasno określił też miejsce, w którym zakonnik mieszkał. Legenda towarzysząca rycinie opisuje jeden $\mathrm{z}$ obiektów w taki sposób: „Abbatia S. Adriani ord. D. Benedicti cum Schola humanior[um] litterar[um] et convictu [Opactwo benedyktyńskie pod wezwaniem świętego Adriana ze szkoła humanistyczną i internatem]"7.

Informacje pochodzące z przywołanych źródeł wskazują jednoznacznie, że Quintinus Duretius właśnie w tym klasztorze spędził część swojego życia i pełnił tam funkcję rektora kolegium ${ }^{8}$. Dzięki wiadomościom zawartym w dziele Bibliotheca Belgica wiadomo ponadto, iż był także zwierzchnikiem gimnazjum założonego przez miasto. Zgodnie $z$ tym, co podaje Sanderus, szkoła powstała w maju 1626. Na jej siedzibę przeznaczono kamienicę stojącą na prawo od ratusza, zajmowaną wcześniej przez sekretarza rady miasta, Joannesa Prielsa. Gros nauczycieli stanowili wykładowcy szkoły elementarnej z Hennegau. Byli to tzw. hieronimiści (Hieronymitae), kontynuatorzy edukacyjnych idei Geerta Grootego ${ }^{9}$. W ich gronie pracował najprawdopodobniej Duretius, a w samym gimnazjum zaczął sprawować najwyższy urząd.

Wzmiankowana przez Blaeu szkoła humanistyczna (schola humaniorum litterarum) stanowiła w czasach zakonnika pierwszy stopień ponadelementarnego kształcenia młodzieży inspirowanego trivium i quadrivium, gdzie wykładano gramatykę, retorykę oraz dialektykę. Nic więc dziwnego, że owocem pracy w tym środowisku stała się książka z dziedziny literatury. Mam tu na myśli wspomniany przez

Wysokiej jakości, lecz achromatyczna kopia znajduje się na stronie: http://repository.tudelft.nl/ view/MMP/uuid\%3Aaleebcb5-979a-48c6-bfcc-8aa9a93a8c99/ (data dostępu: 4 VIII 2018). Należałoby zaznaczyć, że dzieło to jest znane także pod tytułem łacińskim Novum ac magnum theatrum urbium Belgicae Liberae ac Foederatae.

7 Ibidem.

8 Historia klasztoru została przedstawiona przez S a n d e ru s a (op. cit., s. 174-176).

9 Zob. ibidem, s. 170. 
Foppensa zbiór Poesis anagrammatica [...]. Dla poznania Duretiusa ta pozycja wydaje się nadzwyczaj znacząca. Już dla naukowców kolejnego stulecia i, co więcej, badaczy pochodzących ze środowiska benedyktyńskiego, był on bowiem postacią na tyle tajemniczą, że opisując go, wskazywali tylko na fakt jego autorstwa. Potwierdzenie stanowi choćby przywołana wcześniej opinia $\mathrm{z}$ pracy Historia rei litterariae Ordinis $S$. Benedicti, gdzie pojawia się wyłącznie jeden punkt odniesienia pozwalający ustalić tożsamość zakonnika. Padają tam słowa „claruit circa annum 1651". To sformułowanie można przełożyć w sposób przyjęty w zaprezentowanej translacji jako określenie „stał się znany około roku 1651” bądź też jako „dał się zauważyć około roku 1651” lub „szczyt jego działalności przypada około roku 1651”. Bez względu na wersję tłumaczenia wskazany rok to bezsprzecznie data publikacji kolekcji anagramatycznej w oficynie Petrusa Bellerusa.

\section{Autor odkryty dzięki jednej książce}

Na stronie tytułowej poetyckiego zbioru, dzięki któremu Duretius stał się znany, widnieje inskrypcja bardziej rozwinięta niż ta, jaką zapisano w Bibliotheca Belgica. Obejmującej 389 stronic tekstu publikacji nadano zatem tytuł w następującej postaci:

Rhetorum Collegii S. Adriani oppidi Gerardimontani in Flandria „Poesis anagrammatica” sub Quintino Duretio Insulensi monasterii eiusdem S. Adriani Ordinis S. P. Benedicti presbytero religioso. [Poezja anagramatyczna retorów Kolegium św. Adriana w Geraardsbergen we Flandrii, pod kierunkiem Quintinusa Duretiusa $z$ Lille, zakonnika i prezbitera tegoż benedyktyńskiego klasztoru pod wezwaniem św. Adriana.]

U dołu strony znajdują się sygnalizowane już noty dotyczące miejsca i czasu wydania, poniżej których dołączono dopisek, iż utwór został wydrukowany za pozwoleniem przełożonych (superiorum permissu) ${ }^{10}$. Pomiędzy tytułem a adresem wydawniczym drukarz umieścił rycinę przedstawiającą otoczonego aureolą mnicha trzymającego ksieggę i pastorał. W tej postaci, usytuowanej w centrum obrazu, łatwo rozpoznać Benedykta z Nursji. Wskazują na to atrybuty towarzyszące owej postaci. Obok tych, które święty trzyma w ręku, $z$ lewej strony na ziemi znajduje się kruk $z$ kawałkiem chleba, $z$ prawej $z$ kolei pęknięty kielich. Sa to znane $z$ innych przedstawień symbole identyfikujące założyciela zakonu, które nawiązują do epizodów z życiorysu Benedykta ${ }^{11}$. Autor ryciny, sygnujący swe dzieło inicjałami F. V. W.,

10 W egzemplarzu należącym do Staatsbibliothek Bamberg (sygn. 22/L.r.r.o.44), którym posłużono się przygotowując obecne opracowanie, pod nagłówkiem na pierwszej stronie dopisano ręcznie „Sum ex libris Johan Neydecker IV. 21656 [należę do zbioru książek Jana Neydeckera IV. 2 1656]”. Pod tym mianem znane sa dwie osoby żyjace w XVII wieku. Co ciekawe, obaj bohaterowie to mieszkańcy Bambergu. Najprawdopodobniej chodzi o ojca i syna. Zob. H. J. J ä c k, Zweites Pantheon der Literaten und Künstler Bambergs vom XI. Jahrhunderte bis 1844. Bamberg 1844, s. 92. Jeden $z$ nich to lekarz, drugi prawnik. Ten ostatni jest najpewniej autorem rozprawy Disputatio iuridica de maleficis et processu adversus Eos instituendo (Ingolstadii, b. r.), wygłoszonej 19 XII 1629.

11 Zgodnie z biogramem napisanym przez św. Grzegorza Wielkiego (Greg. M. Dial. II, 3; 2, 8), dwukrotnie usiłowano ojca zachodniego monastycyzmu pozbawić życia. Raz podano mu w klasztorze do picia zatrute wino w pucharze, który pękł podczas modlitwy błogosławienia posiłku. Kiedy indziej 
umieścił w tle również elementy architektury ${ }^{12}$. Znajdujące się za postacią zabudowania - od strony wizerunku kruka - sa trudne do zidentyfikowania. Prawa strona obrazu przedstawia natomiast ruiny budowli porośnięte chaszczami. Łatwo rozpoznać, że to relikty alegorycznego wyobrażenia antyku, gdyż w dwu miejscach można zobaczyć sklepienia na planie łuku, które stanowiły najbardziej typowy element starożytnego budownictwa rzymskiego. Artysta chciał, jak się wydaje, wskazać na epokę, w jakiej żył św. Benedykt, na czasy schyłku kultury antycznej i początku nowego świata wieków średnich.

Zarówno tytuł dzieła, jak i pisma umieszczone we wstępnej partii książki stawiaja czytelnika wobec pytania, czy Duretius rzeczywiście był autorem zbioru. Zgodnie z przytoczonym w całości nagłówkiem - wiersze to praca retorów Kolegium św. Adriana. Wszystko miało się dokonać pod kierunkiem (sub) benedyktyna. Podobne sformułowanie znajduje się także w pozwoleniu na druk (Facultas superioris) wystawionym 11 XII 1650 przez opata klasztoru Martina Le Bruna. Stwierdza on, że poezja zawarta w kolekcji została przygotowana przy pomocy mnicha (,auxilio Quintini Duretii religiosi nostri", Rh). To samo przeświadczenie potwierdzone zostaje przez Approbatio wydaną tydzień później przez cenzora Sanderusa, który konstatuje $z$ kolei, iż jest to osiagnięcie adeptów sztuki wymowy, jakiego dokonali pod przewodnictwem profesora Duretiusa (,eloquentiae candidati, duce V. D. Quintino Duretio professore suo publico destinarunt”, Rh). Nie ma więc wątpliwości, że poszczególne utwory to owoc pracy uczniów miejscowego kolegium. Sam benedyktyn odegrał w przygotowaniu zbioru rolę pomocniczą, zaznajamiając młodzież z regułami pisania i - jak można domniemywać - korygując błędy. Potwierdzenie tego przekonania przynoszą również inne teksty marginalne zamieszczone w ksiażce. We wszystkich prawie brak jakichkolwiek odniesień do Duretiusa. W całym dziele jest on postacia wręcz nieobecna. Na wstępie zatem iuventus eloquentiae studiosa (młodzież studiująca sztukę wymowy) zwraca się do opata klasztoru, wspomnianego już Le Bruna (Rh k. $\mathrm{A}_{2} \mathrm{r}-\mathrm{A}_{3} \mathrm{r}$ ). Później „Musa Adrianaei studio florente Lycaei [kwitnąca dzięki nauce Muza szkoły św. Adriana]”, czyli scholares (uczniowie), prosi o życzliwość i mecenat miejscowych dostojników (Magnanimi proceres, Rh k. A $\left.\mathrm{A}_{4} \mathrm{r}-\mathrm{v}\right)$. W końcu wreszcie kieruje do odbiorcy (Ad lectorem) następujące słowa:

Ecce Adrianaei, lima accedente magistri, Gymnasii iuvenum carmina lector habes.

ofiarowano świętemu do jedzenia zatruty chleb. Benedykt nakazał krukowi porzucić bochenek w miejscu, gdzie nie będzie szkodził nikomu. Zob. Św. Grzegorz Wielki, Dialogi. Przeł. W. Sz ołdr ski. Wstęp J. S. B oj ar s ki. Oprac. E. St a nula. Warszawa 1969, s. 61-62, 67-68. Zob. też wyd. krakowskie z roku 2000 (Przeł. E. C zerny, A. Świderkówna. Wstęp A. de V o g ü e. Koment., oprac. M. St a rowi eyski〈s. 136-138, 147-148〉). - Życie świętego Benedykta. 2 Księga Dialogów Świętego Grzegorza Wielkiego. W: Św. Benedykt z Nursji, Reguła. - Żywot. - Komentarze. Przygot. benedyktyni tynieccy. Tyniec 1979, s. 84-85, 91-92.

12 Z dużą dozą prawdopodobieństwa można przyjąć, że miedzioryt został przygotowany przez antwerpskiego chalkografa, współpracującego $z$ P. Rubensem i jego szkoła, F. van den Wyngaerde’a (1614-1679). To on posługiwał się umieszczona w dziele Duretiusa abrewiaturą. Zob. G. K. Nagl er, Die Monogrammisten und die jenigen bekannten und unbekannten Künstler aller Schulen, welche sich zur Bezeichnung ihrer Werke eines figürlichen Zeichens, der Initialen des Namens, der Abreviatur desselben etc. bedient haben [...]. T. 2: CF-GI. München 1860, s. 924. 
[Oto poezja młodzieży ze szkoły św. Adriana -

Czytelniku - ręką nauczyciela skorygowana.] [Rh k. A $\mathrm{A}-\mathrm{v}$ ]

Również utwory gratulacyjne skierowane zostały do uczniów kolegium, a nie do ich profesora ${ }^{13}$. Ostatecznie trzeba zatem przyjąć, że książka rozpowszechniona pod imieniem Duretiusa nie stanowiła w istocie jego własne dzieło. Była to praca zbiorowa przygotowana pod kierunkiem zakonnika. Młodzi poeci nie pozostają zresztą w niej całkowicie anonimowi, gdyż na jej końcu znajduje się wykaz zatytułowany Nomina eorum qui huic "Poesi anagrammaticae” allaboraverunt, gdzie z imienia, nazwiska i pochodzenia wymieniono alfabetycznie 51 współautorów kolekcji (Rh s. 387-389). Przy poszczególnych wierszach brak jednak not informujących, kto $\mathrm{z}$ adeptów sztuki tworzył dany tekst.

Sam pomysł ćwiczeń $z$ dziedziny poetyki i publikowania najlepszych wierszy opracowanych przez młodzież nie był w XVII wieku niczym nowym. Jak ustalono na podstawie jezuickiego dorobku $z$ epoki, anagram należał wówczas do najpopularniejszych postaci twórczości kunsztownej. Lubili go bardzo nauczyciele literatury, jak pisał Maciej Kazimierz Sarbiewski. On sam krytycznie oceniał wartość tego rodzaju dorobku. Poprzedził też Bohuslava Balbína i Laurentiusa Le Bruna w sceptycznym podejściu do przekonania, że przygotowanie anagramu rozwija talent uczniów $^{14}$. Metoda stosowana przez Duretiusa w benedyktyńskim kolegium była zatem identyczna $\mathrm{z}$ tą, jaka posługiwała się ówcześnie liczna grupa wykładowców przedmiotu. Publikacja wierszy studentów sugeruje, że ich pierwsze próby poetyckie uznano za udane. Zdaje się to potwierdzać wspomniany już cenzor Sanderus w swojej Approbatio, podkreślając, iż nie widział chyba innej kolekcji, w której pod kierunkiem nauczycieli tak wyraziście uzewnętrzniłyby się walory intelektualne i moralne młodych ludzi.

Zbiór poezji opracowany przez belgijskich kolegiastów został podzielony na dwie obszerne księgi. Druga $z$ nich obejmuje teksty dedykowane różnorodnym postaciom życia publicznego. Ponieważ nie ma związku z utworami wydanymi drukiem w Krakowie, nie jest w obecnym omówieniu przedmiotem zainteresowania. Partię wstępną zbioru opatrzono tytułem Sacra. Najobszerniejszą część stanowią tam wiersze ku czci świętych, w większej liczbie zwłaszcza Benedykta z Nursji (Rh s. 92-221). Książka rozpoczyna się natomiast od niejednorodnych tematycznie wierszy poświęconych Chrystusowi (Rh s. 2-10). Po nich następują swoiste cykle epigramatyczne, tzn. Stationes Dominicae Passionis, oraz przekształcenia anagramatyczne przygotowane w oparciu o wyrażenie „Iesus Salvator mundi” (Rh s. 11-45). Pomiędzy serią dedykowaną Chrystusowi a tą, która dotyczyła świętych, znalazły się anagramaty ku czci Najświętszej Maryi Panny. Zostały one skategoryzowane podobnie jak te w partii poczatkowej. Najpierw w jednym zbiorze zgromadzono zatem wiersze rozproszone, opracowane na podstawie rozmaitych tytułów maryjnych (Rh s. 46-52).

13 Chodzi tu o P. du Mon s a Praeclarae iuventuti Coll. S. Adriani „Poesim anagrammaticam” felicissimum ingenii partume vulganti, F. G ill o ti u s a In eandem „Poesim anagrammaticam”. Ad adolescentes eiusdem poëseos elucubratores oraz N. Te n e u r a Ad auctores huius „Poeseos anagrammaticae" syncharma.

14 Zob. J. N ow a s z c z u k, Difficillimum poematis genus. Jezuicka teoria epigramatu. Szczecin 2013, S. 189. 
Po nich następują trzy zestawy tekstów. Zbudowano je odwołując się do Litanii loretańskiej, Różańca i liturgicznych świąt obchodzonych dla uczczenia Matki Bożej (Rh s. 53-91). Układ teologiczny całej kolekcji jest bardzo czytelny. Redaktor stosuje gradatio a maiore ad minus, rozpoczynając od Jezusa Chrystusa, poprzez Maryję i świętych, zmierzając ku zwykłym ludziom. Zamysł formalny wydaje się również jasny. W każdym wypadku na pierwszym miejscu postawiono utwory samodzielne, w dalszej partii lokując cykle epigramatyczne.

\section{Publikacja z Krakowa}

Nawet krótka prezentacja dzieła Poesis anagrammatica prowadzi do spostrzeżenia, iż nie jest ono tożsame $z$ tym, jakie ukazało się w Krakowie. Książki wyraźnie różnią się wielkością, zostały też opublikowane pod odmiennymi tytułami. Zbiór z oficyny wdowy i spadkobierców Franciszka Cezarego zawiera wszakże utwory wydrukowane wcześniej w Antwerpii. Łatwo dostrzec, że z całej kolekcji polskiego wydawcę zainteresowała ta część, która obejmuje wiersze ku czci Najświętszej Maryi Panny. Zostały one upowszechnione już tylko pod imieniem Duretiusa i nie można wykluczyć, iż w ten sposób utrwaliło się fałszywe przekonanie o ich autorstwie. Nie wydaje się jednak, jakoby była to pomyłka mało dociekliwego redaktora. Stanisław Szczygielski, benedyktyn i późniejszy bibliotekarz tyniecki, którego list do opata Hieronima Lubomirskiego otwiera krakowską edycję, podaje, że poznał kiedyś osobiście Duretiusa w Salzburgu. Nazywa go „contubernalis”, co może wskazywać, iż mieszkali w jednym klasztorze (Illustrissimo et reverendissimo domino, D. Hieronymo S. R. I. principi [...], L k. $\left.\mathrm{A}_{3} \mathrm{r}\right)^{15}$. Jak wyjaśnia polski zakonnik: rok wcześniej trafiły do jego rak „Quintini Duretii [...] opuscula [dziełka Quintinusa Duretiusa]”, anagramaty „ab hoc nostro Duretio argutee laboratas [błyskotliwie przygotowane przez naszego Duretiusa)" - dorzuca nieco dalej (L k. $\mathrm{A}_{3} \mathrm{r}-\mathrm{v}$ ). Informację następnie powtórzono dwukrotnie w śródtytułach. Tak więc w nagłówku poprzedzającym kolekcję, w której znajdują się odwołania do modlitwy różańcowej, dołączono notę, iż całość została oddana wierszem przez benedyktyna Quintinusa Duretiusa (,versu composita a R. P. Quintino Duretio Ord. S. Benedicti”, L k. Cr). Na wstępie zbioru obejmującego rozproszone epigramaty zapisano $\mathrm{z}$ kolei, iż pochodzą one od tego samego autora („anagram mata quaedam eiusdem authoris”, L k. $\mathrm{C}_{4} \mathrm{v}$ ).

W środowisku polskim całość była bezsprzecznie uznawana za oryginalne

Biogramy polskiego benedyktyna nie zawierają informacji o jego podróży do Salzburga. Promują natomiast tezę, że wykształcenie zdobył na rodzimym gruncie. Zob. W. Kę tr zy ń s ki, „Tynecyja” x. Stanisława Szczygielskiego. „Przewodnik Naukowy i Literacki”. Dodatek do „Gazety Lwowskiej” t. 2 (1874), s. 48. - P. S c z a n i e c ki, Benedyktyni polscy. Zbiór szkiców i opowiadań. Tyniec 1989, s. 272. - R. Witkow s ki, Szczygielski Stanisław OSB. Hasło w: Encyklopedia katolicka. T. 19. Lublin 2013, kol. 16-17. P. S c z a n i e c k i zaznacza jednak w pracy Tyniec (Kraków 1980, s. 112), że benedyktyn odbył jakąś podróż do Austrii. Z kolei dzieło poświęcone historii prowadzonego przez benedyktynów uniwersytetu w Salzburgu wskazuje, że w latach czterdziestych XVII wieku wśród mieszkających w miejscowym konwikcie zakonników byli również studenci z klasztoru w Tyńcu. Zob. Historia Almae et Archi-Episcopalis Universitatis Salisburgensis. Sub cura PP. Benedictinorum. Presbyteri et Monachi Benedictini e Congregatione S. Blasii in Sylva Nigra. Francofurti-Lipsiae 1728, s. 106. 
dzieło mnicha $z$ Geraardsbergen. Nic więc dziwnego, że w poczatkach lat osiemdziesiątych XVII wieku częstochowski paulin Ambroży Nieszporkowicz, nawiązując do jednego $\mathrm{z}$ wezwań Litanii loretańskiej, chwali go za towarzyszacy modlitwie anagramat i jako jego twórce nazywa „illustrissimae Benedictinae familiae decus [ozdoba prześwietnego zakonu benedyktynów]"16. Nie wiadomo, czy sam Duretius i jego uczniowie uświadamiali sobie całą sytuację. Sprawa mogła być komentowana również na lokalnym, flandryjskim gruncie. Dość, że w wydanym w Brukseli w 1678 roku dziełku studentów Kolegium św. Adriana zatytułowanym Musa Pacifica anni chronographicis, versibusque polite concinnata nie widnieje już na stronie tytułowej imię nauczyciela. W opublikowanym 2 lata później zbiorku chronogramów pojawia się on nie jako autor wierszy, lecz jako ich adresat. Warto podkreślić, że tym razem każdemu z nich towarzyszy glosa zawierająca imię twórcy. Chodzi o kolekcję Plausus chronographicus przygotowaną z okazji 50-lecia jego ślubów zakonnych ${ }^{17}$. Jakkolwiek użyto tam rodzimej formy nazwiska DuRetz, treść utworów nie pozostawia wątpliwości, iż chodzi o prezentowanego tu benedyktyna. A ponieważ wiersze opisują go jako starca, dzięki nim wiadomo, że doczekał roku 1680 i pełnił w klasztorze oraz w gimnazjum te same zadania, co wcześniej.

Publikacja z Krakowa poszerza wiadomości dotyczące zakonnika. Jak dotąd, brak ścisłych informacji, kiedy żył Duretius. Punkt odniesienia dla wcześniejszych badaczy stanowił druk kolekcji anagramatycznej. Skoro, zgodnie z danymi zawartymi w liście otwierającym „Litaniae Lauretanae”, Duretius studiował razem ze Szczygielskim bądź przechodził z nim określone etapy formacji zakonnej, mogli być rówieśnikami, a przynajmniej nie dzieliła ich duża różnica wieku. Ten ostatni urodził się w 1616 roku, zmarł natomiast po roku 1685, jak podaje Paweł Sczaniecki ${ }^{18}$. Starsze opracowania oraz Encyklopedia katolicka uściślają, że doczekał 1687 roku ${ }^{19}$. Szczygielski potwierdza ponadto, iż w czasach publikacji „Litaniae Lauretanae” Duretius piastował nadal funkcje profesora w Gerardimontium ( $\mathrm{L} \mathrm{A}_{3} \mathrm{r}$ ). Edycja z krakowskiej oficyny nie mogła ukazać się przed rokiem 1660, gdyż wtedy właśnie komendatoryjnym opatem tynieckim został Lubomirski, do którego zwraca się w liście dedykacyjnym polski mnich ${ }^{20}$. Szczygielski od roku 1661 był w Tyńcu przez 2 lata wykładowcą teologii i opiekunem nowicjuszy, później przeorem. Następnie powierzono mu zadania poza klasztorem. Wrócił do niego po roku 1665 i od 1668 został miejscowym bibliotekarzem ${ }^{21}$. Krakowskie wydanie nie ukazało się raczej

A. Ni e s z p or k ow i c z, Analecta mensae reginalis seu Historia imaginis Odigitriae Divae Virginis Claromontanae Mariae [...]. Cracoviae 1681, s. 53.

Admodum reverendo domino, domino Quintino DuRetz, Monasterii S. Adriani religioso presbytero [...]. Bruxellis 1680. Egzemplarz tej edycji, jakim się posłużono w obecnym opracowaniu, znajduje się w zasobach British Library (sygn. BLL01004056137).

Sczani e ki: Tyniec, s. 115; Benedyktyni polscy, s. 276.

Zob. Kętrzyńs ki, loc. cit. - Witkows ki, loc. cit.

Zob. Opaci tynieccy. W zb.: Monumenta Poloniae historica / Pomniki dziejowe Polski. T. 5. Oprac. członkowie Lwowskiej Komisji Historycznej Akademii Umiejętności w Krakowie. Lwów 1888, s. 605. Życiorys opata przedstawił P. Sczaniecki w książkach Katalog opatów tynieckich (Kraków 1978, s. 193-199) oraz Benedyktyni polscy (s. 260-265).

Zob. Szczygielski Stanisław. Hasło w: Encyklopedia powszechna Orgelbranda. T. 24. Warszawa 1867, s. 593. - Kętrzyńs ki, loc. cit. 
w tym okresie, gdy Szczygielski troszczył się o książnicę zakonną. Kryteria wewnętrzne tekstu dedykacji prowadzą do przekonania, że dokonało się to raczej w początkach lat sześćdziesiątych XVII wieku. Benedyktyn zwracając się do możnego acz młodego protektora pisze, iż wcześniej dedykował mu już dzieło Miracula Deiparae Tuchoviensis (L k. A $\mathrm{r}-\mathrm{v})$. Ukazało się ono drukiem w $1661 \mathrm{roku}^{22}$. Edycja „Litaniae Lauretanae” pojawiła się więc po tej publikacji ${ }^{23}$. Szczygielski poświęcił Lubomirskiemu również kolejny utwór: Aquila Polono-Benedictina, wydany w $1663 \mathrm{roku}^{24}$. Można domniemywać, że wspomniałby o obu dedykacjach, gdyby i ten traktat był już w obiegu. $Z$ dużą dozą prawdopodobieństwa należałoby zatem przyjąc, iż zbiór maryjnych anagramatów ukazał się pomiędzy datami edycji obu wspomnianych dzieł, a więc w latach 1661-1663.

Ustaloną datację zdają się potwierdzać wiadomości zawarte w treści analizowanych tekstów. Jak informuje o. Sczaniecki w biogramie Szczygielskiego, młody benedyktyn, wróciwszy z zagranicy, był pełen entuzjazmu i fascynował się postacią Costantina Gaetana oraz jego działaniami w sferze popularyzacji nauki. Pozostawał także pod dużym urokiem współczesnego sobie erudyty Juana Caramuela y Lobkowitza. W początkach swej pracy na rodzimym gruncie Szczygielski był też przekonany o wyjątkowej roli Tyńca jako ośrodka intensyfikującego badania naukowe ${ }^{25}$. Zbliżone wątki odnaleźć można w liście dedykacyjnym, gdzie autor wychodzi od stwierdzenia, że w wielu częściach świata odżywają studia naukowe oraz powstają uczelnie. Pośród znaczących kolegiów wymienia i to w Grammont, gdzie powstał zbiór anagramatyczny. Jak pisze, sa to pobożne i uczone dziełka (,pia et docta opuscula") ${ }^{26}$. W tym miejscu wywodu daje o sobie znać nuta pedagogiczna. Zakonnik jawi się jako zatroskany nauczyciel, bolejąc, iż dzieło tej wartości nie jest powszechnie dostępne. Traktuje je jako dobry środek wspierania pobożności (,pietatialendae”) i kształtowania myślenia (,ingenio formando”) ${ }^{27}$. Kończy całość życzeniem, by opracowanie zachęciło polskich mnichów do twórczego współzawodnictwa (aemulatio, L). Przesłanie tekstu zdaje się zatem potwierdzać, iż dedykacja zamieszczona w „Litaniae Lauretanae" pochodzi z młodzieńczego okresu twórczości Szczygielskiego. Jak wiadomo, z czasem utracił on zarówno nadzieję na wsparcie ze strony opata Lubomirskiego, jak i przekonanie o nadzwyczajnym posłannictwie Tyńca ${ }^{28}$.

Publikacji maryjnej kolekcji tekstów nie należy raczej przesuwać poza styczeń 1664. Wtedy bowiem ukazał się drukiem jeszcze jeden fragment ze zbioru Poesis anagrammatica. Jakkolwiek Estreicher i inne opracowania uznają książkę Novus

Zob. S. S c zy g i e l s k i, Illibatae semel Matris, semper Virginis castissimae, Tuchoviensis mirabilium operum symbola [...]. Cracoviae 1661.

Korekcie należałoby zatem poddać informację znajdująca się na stronach Bibl. Jagiellońskiej w internetowym opisie książki (http://jbc.bj.uj.edu.pl/dlibra/docmetadata?id=277475\&from=pu blication (data dostępu: 4 VIII 2018〉).

S. S c zy g i els k i, Illustrissimo et reverendissimo domino. D. Hieronymo Lubomirski [...]. W: Aquila Polono-Benedictina in qua beatorum et illustrium virorum elogia, caenobiorum, ac rerum memorabilium synopsis, exordia quoque et progressus. Cracoviae 1663.

Sczani ecki: Tyniec, s. 112; Benedyktyni polscy, s. 273.

$\mathrm{Sczy}$ gi els ki, Illustrissimo et reverendissimo domino, $\mathrm{k} . \mathrm{A}_{3} \mathrm{r}$. Ibidem.

Zob. Sczaniecki, Benedyktyni polscy, s. 274-276. 
Proteus „Iesus Salvator mundi” anagrammatice centies inversus za oryginalny utwór Szczygielskiego, nie jest nim wszakże w istocie. Zestawienie tekstów edycji z Antwerpii i Krakowa potwierdza, że kolekcja anagramów opracowanych poprzez mutacje zwrotu „Jezus Zbawiciel świata” rozpowszechniona przez tynieckiego zakonnika i wzmiankowany już cykl „Iesus Salvator mundi” są identyczne ${ }^{29}$. Co więcej, sam Szczygielski we wprowadzeniu informuje, że utwory są dziełem mnicha Quintinusa $^{30}$. Nie ma zatem wątpliwości, że polska publikacja to kolejna reedycja wierszy napisanych przez belgijskich studentów. Niewykluczone, iż benedyktyna skłoniło do tego dobre przyjęcie „Litaniae Lauretanae”. Ostatecznie zatem korekty wymagają dane zawarte w dawnych omówieniach i u Estreichera, powielone obecnie w Encyklopedii katolickiej, zgodnie z którymi polski zakonnik sam wynalazł 100 różnorodnych anagramów w oparciu o jeden zwrot chrystologiczny ${ }^{31}$.

\section{Dziełka pobożne i uczone}

List do Lubomirskiego nie pozostawia wątpliwości, że to Szczygielski był inspiratorem wydania zbioru maryjnego pochodzącego $z$ flandryjskiego opactwa. Polski redaktor zmienił pierwotny układ wierszy i - kierując się gradatio a maiore ad minorem - na początku umieścił najbardziej rozbudowaną kolekcję, tzn. dziełko zatytułowane "Litaniae Lauretanae” anagrammatice contextae (Litania loretańska w opracowaniu anagramatycznym). W środku antologii znajduje się „Rosarium” sive corona Sanctissimae Deiparae Virginis Mariae (Różaniec, czyli koronka Najświętszej Bogurodzicy Dziewicy Maryi). Całość zamyka niewielki zbiór nie powiązanych ze sobą wierszy. Tę partię nazwano De Sanctissima Deipara Virgine Maria, augustissima caelorum Regina. Anagrammata quaedam eiusdem authoris (Najświętsza Bogurodzica Dziewica Maryja, najczcigodniejsza Królowa niebios. Kilka anagramatów tego samego autora).

\section{Litaniae Lauretanae (Litania loretańska)}

Wynalazek druku pozwolił upowszechnić w środowisku chrześcijan litanie, tzn. modlitwy, na które składają się enumeracje paralelnych fraz zbudowane jako apostrofy mające charakter suplikacji, aklamacji, deprekacji, inwokacji lub laudacji, podzielone przy tym na dwa komplementarne głosy, tzw. partię przewodnika i frazy chóru ${ }^{32}$. W wieku XVI publikowano tak wiele opracowań i tak różnorodnych, że

Zob. Rh s. 11-45. - S. Sczygielski, Novus Proteus „Iesus Salvator mundi” anagrammatice centies inversus [...]. Egzemplarz tej edycji znajduje się w zasobach Zakładu Starych Druków Bibl. Narodowej (sygn. SD XVII.2.6).

30 S. S c zy g i e l s ki, Charissimis in Christo fratribus, celeberrimi Tynecensis Monast. Ordinis S. P. nostri Benedicti professis. W: Novus Proteus Iesus Salvator mundi anagrammatice centies inversus [...].

31 Zob. I. C h o d n i c k i, Dykcjonarz uczonych Polaków, zawierajacy krótkie rysy ich życia, szczególne wiadomości o pismach i krytyczny rozbiór ważniejszych dziet niektórych [...]. T. 3. Lwów 1833, s. 97. - Encyklopedia powszechna, s. 594. - K. E s tr e i c h er, Bibliografia polska, t. 30 (1934), s. 235. - Witkowski, loc. cit.

32 Definicja formy zaczerpnięta została $\mathrm{z}$ książki W. Sa d ow s ki e g o Litania i poezja. Na materiale literatury polskiej od XI do XXI wieku (Warszawa 2011, s. 16-21). 
zwróciło to uwagę Stolicy Świętej. Trudno było policzyć istniejące mutacje tekstów. W poszczególnych wersjach pojawiły się natomiast niedorzeczne, a nawet niebezpieczne - z punktu widzenia teologii - sformułowania ${ }^{33}$. Pobożność, która nazwać można polinomiczną, odpowiadała mentalności ludzi czasów nowożytnych. Kolekcje tytułów i godności często otwierane sa przecież przez pisma $z$ epoki. Reagując na powstała sytuację, papież Klemens VIII wydał zakaz publikowania nowych zbiorów litanijnych bez wcześniejszego uzyskania pozwolenia ze strony Kongregacji Obrzędów Świętych. Zachęcił także, by zachować dawne formy w postaci zawartej w księgach liturgicznych ${ }^{34}$. Jednym $z$ dwóch najważniejszych tego rodzaju modeli była modlitwa pochodząca $z$ Loreto $^{35}$. Rozporządzenie papieskie ograniczyło w jakimś stopniu kreatywność w tworzeniu nowych wezwań, ożywiło natomiast prace wzorujące się na istniejących już litaniach. Stąd też pojawiły się teksty wiążące ją $z$ emblematami czy elogiami ${ }^{36}$. Wydaje się, że to dość znaczacy moment $\mathrm{w}$ dziejach piśmiennictwa. W tym okresie gatunek przekroczył bowiem granice sfery dewocyjnej i znalazł swe miejsce w przestrzeni literatury. Poeci zaczęli opracowywać inwokacje na różne modne sposoby, odpowiadające gustom czytelników. W tym nurcie mieści się również cykl przygotowany przez młodzież z Kolegium św. Adriana. Osnowę zbioru stanowi znana maryjna modlitwa. Skojarzono ją natomiast z anagramem, gatunkiem, który przeżywał w XVII wieku szczyt popularności.

Kolekcja Litaniae Lauretanae zachowuje układ treści typowy dla swej formy i to w postaci występującej w barokowych modlitewnikach. Całość rozpoczyna się zatem od wezwań „Kyrie eleyson, Christe eleyson, Kyrie eleyson”. Te pozostawiono w pierwotnej formie. Kolejne elementy, tzn. apostrofy do Chrystusa i Trójcy Świętej, poddano już anagramatyzacji i każdemu z rozwiązań towarzyszy epigramat, w którym wykorzystano określenie utworzone przez literową roszadę. Podsumowanie partii wstępnej stanowi nowe określenie powstałe z suplikacji „miserere nobis” powtarzanej przez chór. Podobny schemat zastosowano w centrum kolekcji. Zasadniczą część zajmują tam zwroty do Maryi, które doznają transmutacji w nowe wyrażenia, a te z kolei zostają wprowadzone do wierszy. Za rodzaj konkluzji można uznać wariację zwrotu „ora pro nobis [módl się za nami]”, wypowiadanego zwyczajowo po każdej $z$ inwokacji. Autor jest wierny schematowi modlitwy również w zakończeniu. Brak tam wezwań „Agnus Dei”, typowych choćby dla Litanii do Wszystkich Świętych. Duretius zrezygnował $\mathrm{z}$ nich, gdyż struktura zawierająca tylko trzy wątki była typowa dla katalogu maryjnych tytułów $z$ Loreto ${ }^{37}$. Utwór zostaje zamknięty podsu-

Zob. Cle m e n s VIII, Contra edentes, velutentes aliis litaniis, quam hic approbatis, vel a Congregatione Sacrorum Rituum approbandis. W: L. C h e r u b i n u s [i in.], Magnum bullarium Romanum, a Beato Leone Magno usque ad S. D. N. Benedictum XIII. Opus absolutissimum. T. 3. Luxemburgi 1727, s. 193.

Zob. ibidem.

Historia modlitwy została przedstawiona w pracach J. Kútnika (Litania loretańska. Przeł. J. Zy chowicz. Red. A. Bardecki. Kraków 1983) oraz G. Bas adonny i G. Santarelle go (Litania loretańska. Przeł. A. D u dzińs ka-F a c c a. Warszawa 1999, s. 11-37).

Zob. P. S t o e gl e r, Asma poeticum Litaniarum Lauretanarum. B. m., 1636. - I. P. B e rle n d u s, Elogia gloriosissimae Virginis Deiparae Mariae ad litanias eiusdem Lauretanas [...]. Przeł. W. W e i s sha u t. Lincii-Campoduni 1677. - I. Oxoviensis, Elogia Mariana ex „Litanii Lauretanis” deprompta [...]. Augustae Vindelicorum 1709.

Zob. Kútnik, op. cit., s. 25-26. 
mowująca prośby modlitwą. Wyraża ona to samo przesłanie, które mają teksty w książeczkach do nabożeństwa. Tutaj oddano ją jednak w metrum elegijnym.

Zestaw 44 anagramów (utworzonych na podstawie wezwań), stanowiących centrum dzieła, można zobrazować w postaci następującego schematu.

\begin{tabular}{|c|c|}
\hline Wezwanie & Anagram \\
\hline $\begin{array}{l}\text { Sancta Maria } \\
\text { (Święta Maryjo) }\end{array}$ & $\begin{array}{c}\text { Amantis arca } \\
\text { (Arka miłującego) }\end{array}$ \\
\hline $\begin{array}{c}\text { Sancta Dei genitrix } \\
\text { (Święta Boża Rodzicielko) }\end{array}$ & $\begin{array}{c}\text { Excitans digna erit } \\
\text { (Pobudzając, będzie godna) }\end{array}$ \\
\hline $\begin{array}{c}\text { Sancta Virgo Virginum } \\
\text { (Święta Panno nad pannami) }\end{array}$ & $\begin{array}{c}\text { Tu nunc agis mira vigor } \\
\text { (Ty, siło życia, dokonujesz rzeczy } \\
\text { nadzwyczajnych) }\end{array}$ \\
\hline $\begin{array}{c}\text { Mater Christi } \\
\text { (Matko Chrystusa) }\end{array}$ & $\begin{array}{c}\text { Micat terris } \\
\text { (Jaśnieje blaskiem po świecie) }\end{array}$ \\
\hline $\begin{array}{l}\text { Mater Diuinae gratiae } \\
\text { (Matko laski Bożej) }\end{array}$ & $\begin{array}{c}\text { E Maria regnat Dei vita } \\
\text { (Poprzez Maryję króluje życie Boże) }\end{array}$ \\
\hline $\begin{array}{c}\text { Mater purissima } \\
\text { (Matko najniewinniejsza) }\end{array}$ & $\begin{array}{c}\text { Summa parit reis } \\
\text { (Rodzi dla winowajców najwspanialsze rzeczy) }\end{array}$ \\
\hline $\begin{array}{l}\text { Mater castissima } \\
\text { (Matko najczystsza) }\end{array}$ & $\begin{array}{c}\text { Mittam escas aris } \\
\text { (Poślę pokarmy na ołtarze) }\end{array}$ \\
\hline $\begin{array}{c}\text { Mater inviolata } \\
\text { (Matko nieskazitelna) }\end{array}$ & $\begin{array}{c}\text { En tali vita amor } \\
\text { (Oto dzięki takiemu życiu miłość) }\end{array}$ \\
\hline $\begin{array}{c}\text { Mater intemerata } \\
\text { (Matko nienaruszona) }\end{array}$ & $\begin{array}{c}\text { Itane terram amet? } \\
\text { (Czyż tak nie kocha ziemi?) }\end{array}$ \\
\hline $\begin{array}{l}\text { Mater amabilis } \\
\text { (Matko godna miłości) }\end{array}$ & $\begin{array}{c}\text { Amat mirabiles } \\
\text { (Kocha tych, którzy są niezwykli) }\end{array}$ \\
\hline $\begin{array}{l}\text { Mater admirabilis } \\
\text { (Matko godna podziwu) }\end{array}$ & $\begin{array}{c}\text { Mira ardebit malis } \\
\text { (Zadziwiająca płonie miłością do złych) }\end{array}$ \\
\hline $\begin{array}{c}\text { Mater Creatoris } \\
\text { (Matko Stworzyciela) }\end{array}$ & $\begin{array}{c}\text { Rite certas amor } \\
\text { (Miłości, walczysz słusznie) }\end{array}$ \\
\hline $\begin{array}{l}\text { Mater Saluatoris } \\
\text { (Matko Zbawiciela) }\end{array}$ & $\begin{array}{c}\text { Salutaris a morte } \\
\text { (Zbawczyni od śmierci) }\end{array}$ \\
\hline $\begin{array}{l}\text { Virgo prudentissima } \\
\text { (Panno najroztropniejsza) }\end{array}$ & $\begin{array}{c}\text { Prudentis virga Mosi } \\
\text { (Różdżka roztropnego Mojżesza) }\end{array}$ \\
\hline
\end{tabular}


Virgo veneranda

(Panno godna szacunku)

Virgo praedicanda

(Panno zasługująca na chwałę)

Virgo potens

(Panno potężna)

Virgo clemens

(Panno łaskawa)

Virgo fidelis

(Panno wierna)

Speculum Iustitiae

(Lustro Sprawiedliwości)

Sedes Sapientiae

(Siedzibo Mądrości)

Causa nostrae laetitiae

(Przyczyno naszej radości)

Vas spirituale

(Naczynie duchowe)

Vas honorabile

(Naczynie zaszczytne)

Vas insigne devotionis

(Znakomite naczynie pobożności)

Rosa mystica

(Różo mistyczna)

Turris Dauidica

(Wieżo Dawidowa)

Turris eburnea

(Wieżo z kości słoniowej)

Domus aurea

(Budowlo ze złota)

Foederis arca

(Arko Przymierza)

Ianua caeli

(Bramo nieba)
Vna erudio regna

(Sama pouczam królestwa)

O pura, Regi dicanda!

(O czysta, poświęcona Królowi!)

Sinu protego

(Chronię łonem)

Lucem resigno

(Objawiam światło)

Is fulgor diei

(Ten blask dnia)

Pietatis luce visum

(W świetle pobożności zobaczone)

Sane es Dei pietas

(Rzeczywiście jesteś łaskawością Boga)

Ter io, sancta es alia Eua

(Po trzykroć „brawo”, druga Ewo, jesteś święta)

Leuat suspiria

(Lagodzi westchnienia)

En arbos oliua

(Oto drzewo oliwne)

Suauis est dono ingenii

(Jest słodka przez wrodzony dar)

Ista, ros amici

(Ona, rosa przyjaciela)

Ars diua dicitur

(Jest nazywana boską sztuką)

Tune rubra eris?

(Czyż Ty nie będziesz w czerwieni?)

Sum aura Deo

(Jestem pogodą dla Boga)

Sacra Dei fero

(Niosę świętości Boga)

Ei vnica ala

(Jedyne skrzydło dla niego) 
Stella matutina

(Gwiazdo zwiastująca brzask)

Salus infirmorum

(Zdrowie chorych)

Refugium peccatorum

(Ucieczko grzeszników)

Consolatrix afflictorum

(Pocieszycielko zasmuconych)

Auxilium Christianorum

(Wspomożenie chrześcijan)

Regina Angelorum

(Królowo Aniołów)

Regina Patriarcharum

(Królowo Patriarchów)

Regina Prophetarum

(Królowo Proroków)

Regina Apostolorum

(Królowo Apostołów)

Regina Martyrum

(Królowo Męczenników)

Regina Confessorum

(Królowo Wyznawców)

Regina virginum

(Królowo Dziewic)

Regina Sanctorum omnium (Królowo wszystkich Świętych)
Astat, lumen alit

(Pomaga, pielęgnuje światło)

Nisu flammis vror

(Wspomagając, staję w płomieniach)

E gemitu fac cor purum

(W udręce uczyń serce czystym)

Altrix lac format confiso

(Żywicielka karmi mlekiem tego, kto zaufał)

Lux Christi, via animorum

(Światło Chrystusa, droga umysłów)

En regnum a gloria

(Oto królestwo dzięki chwale)

Primaria curat regna

(Troszczy się o wspaniałe królestwa)

Pignore pura Mater

(Matka czysta dzięki poręczeniu)

Virgo planto amores

(Jako dziewica sadzę zawiązki miłości)

In ara mirum gerit

(Na ołtarzu dokonuje cudu)

Vigens fers coronam

(Żyjąca, dźwigasz koronę)

Ingenium irriga

(Ożyw wrodzone zdolności)

Vt geram Numinis coronam

(Obym niosła koronę Boga)

Zestaw inwokacji jest zbieżny z tym, jaki wykorzystywano w XVII-wiecznej liturgii $^{38}$. W spisie brak niektórych zwrotów znanych $\mathrm{z}$ późniejszych edycji, jak choćby „Mater boni consilii [Matko dobrej rady]”, „Regina sine labe originali concepta [Królowo bez grzechu pierworodnego poczęta]”, „Mater sacratissimi rosarii [Mat-

- Fasciculus sacrarum orationum et litaniarum [...]. Monachii 1618, s. 161-165. 
ko różańca świętego]". Te pojawiły się jednak na innym etapie historii ${ }^{39}$. Wykorzystano natomiast apostrofe „Auxilium Christianorum [Wspomożenie wiernych]”, którą kilkadziesiąt lat wcześniej wprowadzono do katalogu za papieża Piusa V po bitwie pod Lepanto (1571).

Wszystkie rozwiązania i towarzyszace im epigramaty zawarte w krakowskiej edycji są zbieżne $\mathrm{z}$ tymi, jakie zamieszczono w zbiorze $\mathrm{z}$ Antwerpii. Polski wydawca ingerował jedynie w te miejsca, gdzie było to konieczne. Tak więc dołącza do całości anagram określenia „Consolatrix afflictorum” w postaci, jaka już tu zaprezentowano. Tego fragmentu najprawdopodobniej przez niedopatrzenie brak w wersji pierwotnej (Rh s. 70-71). Redaktor zmienia też przy wezwaniu „Regina virginum” wcześniejszą permutację „ingenuum irriga” (Rh s. 74) na „ingenium irriga” (L). Jego modyfikacja $\mathrm{w}$ tym wypadku była jednak błędem. Sformułowanie nie stanowi bowiem czystego anagramu w odróżnieniu od tego, który znajduje się w kolekcji pochodzącej z Gerardimontium.

W opracowaniu poszczególnych wezwań zastosowano normy powszechnie akceptowane na gruncie barokowego pisarstwa. Autorom zależało, by formy literackie - nazwane przez jezuitę Balbína najbardziej pracochłonnym rodzajem poezji - były poprawne, a zatem, by wszystkie litery podstawowego zwrotu znalazły się $\mathrm{w}$ określeniu utworzonym dzięki przekształceniom ${ }^{40}$. Jak było w zwyczaju, litery „u” oraz „V” stosowano zamiennie, co pojawia się w wielu przykładach zamieszczonego indeksu. Podobnie za ekwiwalent „i” uznawano „y”, co dostrzegamy w anagramie wezwania „Regina martyrum”. Wierność istniejącej tradycji widać także w zastosowanej rytmizacji. Jakkolwiek w kilku wierszach posłużono się mniej pospolitymi miarami, zasadnicze metrum epigramatów stanowi dystych elegijny. Jeśli idzie o same anagramy, trzeba przyznać, że w porównaniu $z$ innymi przykładami $z$ epoki można uznać je za celne, gdyż same w sobie zawierają jakąś myśl logiczną, co nie zawsze się udawało. Najmocniej rozpowszechnionymi postaciami przekształceń literowych były transformacje imion i nazwisk. W opracowaniu uczniów ze szkoły Duretiusa zastosowano odmienny model. Teksty stanowiące źródło przekształceń są tam bowiem bardziej rozbudowane. W swym charakterze zbliżają się jednak do wersji imiennej ze względu na to, iż wezwania litanijne to jakaś forma metaforycznego opisu postaci. Zwyczajowo anagram wyróżniano w wierszu krojem liter, zwykle kapitała ${ }^{41}$. W obu edycjach litanii zastosowano wszakże inne rozwiązanie. Wielkimi znakami wydrukowano tylko imiona „Jezus” i „Maryja”. Same anagramy sa plastycznie zapisane prostą czcionka, podczas gdy pozostała część utworu - kursywą. Autorowi niespecjalnie zależało na podkreślaniu transmutacji opracowanej w tekście. Wydaje się to pewnym novum i zwraca szczególną uwagę. W niektórych wypadkach, jak choćby przy wezwaniach „Sedes Sapientiae” (Rh s. 64; L) czy „Vas honorabile” (Rh s. 66; L) wyrazy „es” oraz „en”, które stanowią część anagramu, nie pojawiają się w ogóle w wierszu.

Metoda, jaką zastosowano przygotowując epigramaty, jest zbliżona do tej,

B. Ba lbín i Verisimilia humaniorum disciplinarum, seu Judicium privatum de omni litterarum (quas humaniores appellant) artificio [...]. Lipsiae 1687, s. 183. Zob. też N ow a s z c z u k, op. cit., s. 189. Zob. Now a s z c zuk, op. cit., s. 193. 
która posługiwano się w emblematyce. Twórcy potraktowali rozwiązania anagramatyczne jako swoiste lemmaty. Ich rozwinięcie lub eksplikację zawiera towarzyszący im epigramat. Jego głównym zadaniem było zatem wytłumaczenie wykreowanego sformułowania poprzez odniesienie go do Maryi. $Z$ tej racji znajdujące się $\mathrm{w}$ zbiorze utwory wydaja się jasne i proste w przekazie, pozbawione argucji. Taki model opracowania nie odbiega od standardów epoki. Jak zauważa Jürgen Nowicki, wzajemne przenikanie sie epigramatyki i emblematyki to cecha charakterystyczna pisarstwa czasów nowożytnych ${ }^{42}$. Janusz Pelc stwierdza, że można mówić nawet o pewnego rodzaju ekspansji form plastycznych, zwłaszcza w obrębie tych gatunków, które posiłkowały się w swej strukturze krótkimi utworami wierszowanymi ${ }^{43}$. Ostatecznie więc kolekcja belgijskich studentów stanowi świadectwo zainteresowań poetyckich oraz barokowych upodobań literackich. Reprezentuje zarazem ciekawe podejście w stosowaniu anagramu w tekście wierszowanym. Nie jest w tym zreszta odosobniona. Dość wspomnieć, że pochodzący z 1689 roku Iubilus Marianus Augustina Casimira Redeliusa i opublikowany pół wieku po antwerpskiej edycji zbiór Litaniae Lauretanae tegoż autora zostały przygotowane w identyczny sposób ${ }^{44}$. Do wszystkich wezwań modlitwy poeta utworzył anagramy, które wykorzystał następnie w wierszach. W jednej z książek ubogacił całość chronostychami. Podobnie jak u Duretiusa - w utworach swobodnie rozmieścił słowa ułożonych zwrotów, wyróżnił je kursywą w tekście prostym lub drukiem wertykalnym w zapisie pochyłym. Kapitałe wykorzystał tylko w imionach albo dla oddania daty. Można zatem sądzić, że zarówno warstwa edytorska, jak i normy poetyckie zastosowane w polskiej edycji Litaniae Lauretanae odpowiadały sztuce wydawniczej, zasadom twórczym oraz upodobaniom czytelników barokowych.

\section{Różaniec (Rosarium)}

Druga część publikacji, tzn. Rosarium sive corona Sanctissimae Deiparae Virginis Mariae, to również literacka wersja popularnej katolickiej modlitwy maryjnej, Różańca. Redaktor wydania $\mathrm{z}$ oficyny wdowy i spadkobierców Franciszka Cezarego rozwija niektóre elementy pierwszej edycji dziełka, inne upraszcza. Zwięzły tytuł zawarty w książce sygnowanej imieniem flandryjskiego benedyktyna - w postaci Rosarium Sanctae Virginis Mariae - poszerza o wyjaśnienie, iż chodzi o koronkę (corona); do imienia Maryi dorzuca tytuł Deipara (Boża Rodzicielka), a wykorzystany przymiotnik „sanctus” stawia w gradus superlativus (Rh s. 76). Dołącza także informację, że całość została oddana wierszem z zastosowaniem biblijnych wyrażeń pochwalnych oraz - co już sygnalizowano - stanowi owoc pracy Duretiusa (Ex S. Scripturae elogiis versu composita a R. P. Quintino Duretio Ord. S. Benedicti, $\mathrm{L}$ k. Cr). W obu wydaniach poniżej tytułu znajduje się anagram słów „Rosarium

J. Nowicki, Die Epigrammtheorie in Spanien vom 16. bis 18. Jahrhundert. Eine Vorbereit zur Geschichte der Epigrammatik. Wiesbaden 1974, s. 75-82. cinnatus [...]. Augustae Vindelicorum 1689; „Litaniae Lauretanae”, quinquaginta epigrammatibus, et totidem anagrammatibus exhibitae [...]. Augustae, b. r. 
Sanctae Virginis Mariae [Różaniec Świętej Dziewicy Maryi]”, w postaci sformułowania „vera arma sinceri amoris tui signa [znaki twojej szczerej miłości to prawdziwa broń]” (Rh s. 76). Sentencjonalnie brzmiące wyrażenie wykorzystano następnie w epigramacie. W krakowskiej publikacji pominięty zostaje natomiast bardzo osobliwy wiersz poprzedzony nagłówkiem „Praeparatio [Przygotowanie]”. Powstał on dla uczczenia roku jubileuszowego 1650 (Rh s. 76-77). Niewykluczone, iż polski wydawca przygotowujaç książkę do druku przeszło dekadę później passus ten uznał za nieaktualny ${ }^{45}$.

Inna część tej partii kolekcji, której nadano tytuł Rosarium, jest identyczna z pierwowzorem pochodzacym z Belgii. Każdy z 6 utworów ma 10 dwuwierszy. Ostatni z nich, opisany jako „Oblatio [Ofiarowanie siebie]”, został zbudowany z zastosowaniem akro- i telestychu wezwania „Ave Maria” i stąd zamyka się w 16 liniach (Rh s. 81; L k. $\mathrm{C}_{3} \mathrm{v}-\mathrm{C}_{4}$ r). Poszczególne epigramaty poprzedzono nota Pater noster, co bez wątpienia wskazuje, iż należy tu odmówić Modlitwę Pańska. Jak zatem widać, zbiorowi nadano strukturę modlitwy maryjnej w jej XVII-wiecznej postaci. Dawniej odróżniano bowiem różaniec w formie obejmującej 5 tajemnic od tego w typie koronki ${ }^{46}$. Tytuł krakowskiego wydania nie pozostawia watpliwości, że chodzi o ów ostatni gatunek. Obejmował on 6 części. W każdej z nich trzeba było dziesięciokrotnie wyrecytować Zdrowaś Maryjo. Repetycję poprzedzano odpowiednim wezwaniem nawiązującym do życiorysu i posłannictwa Najświętszej Maryi Panny ${ }^{47}$.

Novum wersji przekazanej przez Duretiusa stanowi to, że całość oddano wierszem. Inaczej niż w rozpowszechnionej wśród wiernych wersji - modlitwę uporządkowano, kierując się nie tyle biegiem wypadków historii zbawienia, ile układem ksiag biblijnych. Jak wspomniano, polski edytor zwraca na to uwagę wprost, dodając śródtytuł. Również czytelnik książki $z$ Antwerpii był świadom zamysłu twórcy, gdyż na marginesie metrycznego tekstu zapisano sigla wskazujące, skąd zaczerpnięto poszczególne elogia. Samo przydawanie Maryi tytułów odwołujących się do Pisma Świętego nie było niczym nowym w czasach Duretiusa i Szczygielskiego. Posługując się taką metodą, układano różne formy: litanie lub - jak w dziele Pancarpium Marianum - emblematy ${ }^{48}$. W tym ostatnim zbiorze pojawia się wiele zawołań, które wykorzystano później w Poesis anagrammatica. Różnica między opracowaniami polega jedynie na tym, że jezuita Joannes David pogrupował wezwania $\mathrm{w}$ kolekcje powiązane $\mathrm{z}$ określonymi prawdami teologicznymi, podczas gdy w wersji studentów Kolegium św. Adriana posłużono się układem ksiąg w Biblii. Uznanie

Sam epigramat wart jest zauważenia ze względu na rzadkie opracowanie artystyczne. Podobnie jak inne utwory - Rosarium ma 10 dystychów. Każdy z nich kończy się zachęcającym do recytacji Pozdrowienia Anielskiego wezwaniem „Ave”. Co interesujące, w dwuwierszach zawarto chronostych wspomnianego roku 1650. Data została zapisana kapitałą. Takie wyróżnienie dotyczy w poszczególnych liniach nie tylko wybranych, lecz wszystkich wykorzystanych liter spośród 7 znaków alfabetu, jakie stosowano dla oddania wartości cyfrowych. Bez wątpienia pokazuje to niepospolitą biegłość poety w aplikowaniu środków poezji kunsztownej.

46 Zob. Sailliu s, op. cit., s. 243-244.

47 Zob. Beatissimae Virginis Mariae rosarium, omnia prope misteria nostrae salutis complectens. Pragae 1629.

48 Zob. Litaniae secundae ex Sacra Scriptura sumptae. W: Sailliu s, op. cit., s. 250-253. I. J. D a vid, Pancarpium Marianum, septemplici titulorum serie distinctum [...]. Antverpiae 1607. 
dla takiego rodzaju twórczości zdaje się potwierdzać popularność wierszy z Gerardimontium. Jak poświadcza nota zamieszczona na końcu zbioru, opublikowany w dziele tekst miał również szczególną formę materialną. Został wywieszony przed figura Maryi w kolegium benedyktyńskim w Afflighem w Brabancji (Rh s. 82; L k. $\mathrm{C}_{4}$ r). Trudno stwierdzić, o jakie opracowanie chodzi. Mógł to być jakiś druk ulotny, rękopis albo obraz. Jeśli wiąże się to z plastycznym wyobrażeniem, rodzi się pytanie o to, czy zaprezentowano tylko elogia, czy też całe wiersze. Wprowadzenie zaimka wskazującego „hoc" w zastosowanym w książce wyrażeniu „ten Różaniec” sugeruje, że chodzi raczej o ową drugą sytuację. Nie da się również wykluczyć, iż dziełko z klasztoru istniało wcześniej niż wersja drukowana wierszy, Duretiusowi zaś zależało na rozpowszechnieniu odkrytej poezji. Rosarium odstaje bowiem od reszty zbioru, ponieważ poza literową roszadą nazwy modlitwy brak tam innych tego typu rozwiązań, a przecież całości nadano tytuł Poesis anagrammatica. Szczygielski spostrzegł to najprawdopodobniej, przygotowując nowe wydanie, gdyż przysłówek „anagrammatice” odniósł tylko do zestawu tekstów związanych z litanią loretańską.

\section{Anagrammata quaedam eiusdem authoris (Niektóre anagramaty tego samego autora)}

Ostatnią z trzech części krakowskiego zbioru stanowią różnorodne utwory maryjne, które nie wyglądają na jednolitą kolekcję. Polski wydawca dokonał kilku - lecz mało znaczących - poprawek w stosunku do pierwotnej wersji. Zmienił zatem składnię zastosowaną $w$ tytule i pominął wiersz ułożony $z$ okazji wspomnianego już jubileuszu roku 1650 (Rh s. 46; L k. C v). Pozostałe 11 anagramów wraz z towarzyszącymi im epigramatami przedrukowano bez zmian. Punktem wyjścia mutacji literowych są różnorodne tytuły Najświętszej Maryi Panny w typie Virgo Maria (Dziewica Maryja), Sancta Maria Mater Dei (Święta Maryja Matka Boża) czy Mater Iesu (Matka Jezusa) (Rh s. 46-52; L C4v-C5 n.). Całość opracowano z zastosowaniem opisanych już reguł. Uwagę zwracają dwa epigramaty, gdzie wykorzystano nowe rozwiązania kunsztowne, a mianowicie połączenie akro- i mezostychu. Pomysł jest tym bardziej ciekawy, że litery otwierające tekst czytane $z$ góry ku dołowi tworzą tytuł maryjny, który stanowił podstawę przekształceń, wyróżnione litery w biegu linii składają się $\mathrm{z}$ kolei na tekst anagramu.

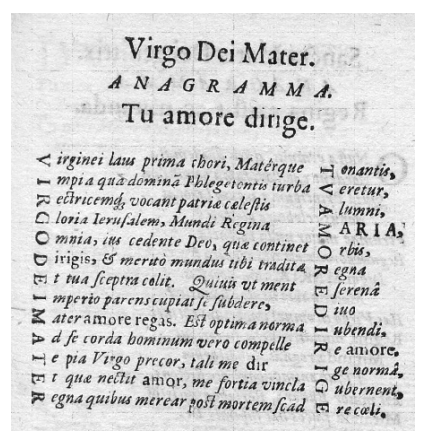

Akrostych i mezostych w krakowskiej publikacji (L) 


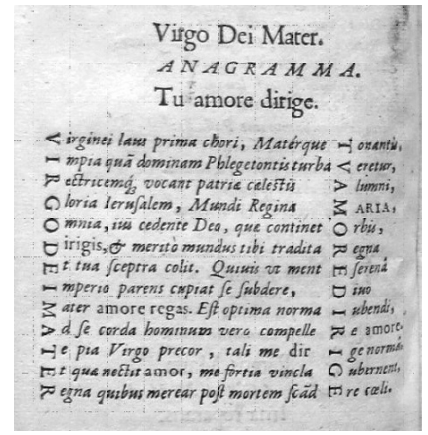

Opracowanie kunsztowne w edycji z Antwerpii (Rh s. 48)

Tego rodzaju rozwiązanie pojawia się przy transmutacjach zwrotu „Virgo Dei Mater” oraz „Virgo Mater Iesu” (Rh s. 48, 51; L). Jakkolwiek tyniecki zakonnik umieścił kolekcję rozproszonych utworów w końcowej partii książki, uznał ją jednak za wartościową i godną upowszechnienia. Pominął natomiast ostatnią z czterech części dzieła uczniów Duretiusa, gdzie w osobnym cyklu epigramatycznym - Festa Mariana anagrammatibus illustrata - opisano liturgiczne święta maryjne (Rh s. 82-91).

Niewielkie barokowe dzieło odnotowane przez Karola Estreichera wtajemnicza w wiele aspektów dawnej twórczości poetyckiej. Stawia też czytelnika wobec dylematów w kwestiach dość zasadniczych, np. autorstwa zbioru. Jak się okazało, Quintinus Duretius znany i identyfikowany tylko dzięki jednej opublikowanej książce, w istocie nie jest jej autorem. Powstała ona bowiem jako owoc literackich wysiłków uczniów powierzonych jego pieczy. Utrwalenie nie do końca prawdziwej wersji wypadków dokonało się również za sprawą polskiej edycji fragmentów dzieła. Benedyktyn Stanisław Szczygielski, który na jakimś etapie życia zetkną się z flandryjskim wykładowca, kilkakrotnie podkreśla, że właśnie Duretius jest autorem tekstów. Spośród bogatego zasobu poezji redaktor krakowskiej publikacji wybrał utwory poświęcone jedynie Maryi Dziewicy. Z czterech osobnych partii materiału pierwszego wydania, które można określić jako opera Mariana, w Polsce wydano drukiem trzy. Są one świadectwem szczególnego rodzaju kreatywności poetów, polegającej na łączeniu struktury modlitw $\mathrm{z}$ tekstami artystycznymi. W ich wypadku można mówić o pewnej „literaturyzacji” form dewocyjnych. Opera Mariana stanowią także swoiste świadectwo rodzenia się na gruncie pisarstwa nowych species. W zakresie genologii dostrzeżono też zmianę w sposobie opracowania epigramatów. Zasadniczym zadaniem poety stało się nie tyle wykorzystanie samego anagramu, ile raczej wytłumaczenie jego znaczenia. Ostatecznie nie wydaje się, by dzieło przez Estreichera przypisane Duretiusowi reprezentowało jedynie wewnątrzbenedyktyńskie tendencje twórcze. Można je uznać bardziej za exemplum tendencji powszechnych. We wszystkich prześledzonych tekstach dają się bowiem zauważyć elementy typowe dla epoki, a zatem w płaszczyźnie literackiej szczególne upodobanie w stosowaniu anagramów i rozwiązań kunsztownych, w dziedzinie religii z kolei - kultywowanie maryjnej pobożności laudacyjnej, zwłaszcza zaś panegirycznej polinomii opartej na multiplikowaniu antonomazji. 
Abstract

JAROSŁAW NOWASZCZUK University of Szczecin

\section{WORKS DISSEMINATED UNDER THE NAME OF DURETIUS IN CRACOW EDITION}

A collection of poems entitled „Litaniae Lauretanae” anagrammatice contextae. Corona quoque V. Beatissimae, ex S. Scripturae elogiis versu composita gives an insight into the artistic work reality and into many aspects of the baroque poetic workshop. Quintinus Duretius (Quentin DuRetz), to whom the collection is attributed, is indeed not its author. The poems are the effects of exercises in writing done by his apprentices, and were published in Antwerp in the year 1651. The false information about the collection's authorship became also fixed due to the Poles. A Benedictine monk Stanisław Szczygielski claims in his writings that it was Duretius who authored the texts which were reedited in Cracow. From a rich collection of poetry contained in Rhetorum Collegii S. Adriani oppidi Gerardimontani in Flandria "Poesis anagrammatica” the Polish editor selected only such pieces which relate to Virgin Mary. Out of four separate parts of the first edition issued by the widow and Franciszek Cezary's inheritors' publishing house three were printed. They evidence a peculiar kind of creativity of young poets from Benedictine college which mingled a prayer structure with artistic texts. In the analysed pieces one discerns elements typical of baroque, so in a literary layer a strong affinity to anagrams and artistic expositions, while in the sphere of religion-cultivation of Marian laudatory piety, especially panegirycal antonomasia. 